\title{
Policy for the Treatment of Insulting and Sensitive Lexical Items in the Woordeboek van die Afrikaanse Taal
}

\author{
formulated by
}

\section{P. Harteveld and A.E. van Niekerk, Bureau of the Woordeboek van die Afrikaanse Taal, Stellenbosch, South-Africa}

\footnotetext{
Abstract: Outline of the policy for the treatment of insulting and sensitive lexical items in the Woordeboek van die Afrikaanse Taal:

\section{Common to all sensitive lexical items}

- all simplexes, compounds and expressions are lemmatized

- all conform to the general usage criterion of the Bureau

- clear and correct labelling takes place, which also applies to insulting synonyms

- the metalanguage is neutral

- no collocations or editorial usage examples are given

- citations (where included) are chosen with care

- articles are checked by advisors to the Bureau
}

\section{A. Racist terms}

1. Treatment in the WAT

(a) Wholly racist lexical items

- for the definition, the item is referred to the most commonly used synonym; no racist synonyms are, however, given at neutral or racist lexical items

- no semantic oppositions are given

- no citations are given

- expressions are explained; no synonyms, antonyms, references and illustrative material are given with such expressions

- the same manner of treatment applies to racist expressions under neutral lemmas

- complete treatment takes place in electronic form (see 2 below)

(b) Partially racist lexical items

- neutral semantic distinctions are treated in full

- racist semantic distinctions and expressions are treated as wholly racist lexical items

This policy has been accepted by the Board of Control of the Bureau of the WAT as its official policy for the treatment of insulting and sensitive lexical items in the Woordebock van die Afrikaanse Toal. The Bureau gladly accepts comments on this document. 
2. Treatment in the electronic manuscript

- references to or the noting of synonyms and semantic oppositions are given

- citations are given

- electronic manuscript is available on request

B. Sexist terms and sensitive lexical items which indicate stigmatized sexual phenomena, practices and preferences among people

- the definition is given at the most commonly used neutral synonym

- references to or the noting of synonyms are given

- antonyms and formal references are given

- citations are given

- expressions are explained

C. Sensitive lexical items which indicate stigmatized physical or mental conditions and phenomena among people

- treatment as in B above

D. Sensitive lexical items within a social, political and religious structure

- treatment as in B above

E. Obscene and vulgar lexical items, abusive language and swear-words

- treatment as in $B$ above

Keywords: POLICY, TREATMENT, INSULTING LEXICAL ITEMS, SENSITIVE LEXICAL ITEMS, DICTIONARY, WOORDEBOEK VAN DIE AFRIKAANSE TAAL, SIMPLEXES, COMPOUNDS, EXPRESSIONS, GENERAL USAGE CRITERION, LABELLING, SYNONYMS, METALANGUAGE, COLLOCATIONS, EDITORIAL USAGE EXAMPLES, CITATIONS, ADVISORS, RACIST LEXICAL ITEMS, NEUTRAL LEMMAS, ELECTRONIC MANUSCRIPT, REFERENCES, SEMANTIC OPPOSITIONS, SEXIST TERMS, STIGMATIZED SEXUAL PHENOMENA, STIGMATIZED PHYSICAL CONDITIONS, STIGMATIZED MENTAL CONDITIONS, POLITICAL ITEMS, RELIGIOUS ITEMS, OBSCENITIES, VULGARISMS, ABUSIVE LANGUAGE, SWEAR-WORDS

Opsomming en Sleutelwoorde: Sien die Afrikaanse weergawe hier bo.

\section{Introduction}

When it concerns the treatment of insulting and sensitive lexical items in the WAT, it is the approach of the Bureau of the WAT to pursue its ideal of comprehensiveness, but also to follow a sensitive treatment policy. This sensitivity must also be reflected in the metalanguage of the WAT.

The Bureau's endeavour at comprehensiveness applies to the macro- as well as the microstructure of the WAT. With respect to the macrostructure, comprehensiveness refers to the number and variety of lexical items which are 
included in the dictionary for treatment; with respect to the microstructure, comprehensiveness refers to the number and variety of the different information types found in the articles.

Comprehensiveness in the macro- and microstructure is a relative concept. With regards to the macrostructure, no dictionary is completely comprehensive in its inclusion of lexical items. A dictionary can be such mainly with respect to the representativeness of the different kinds of language expressions. The exhaustiveness of inclusion in the different categories of a particular dictionary and between corresponding categories in different dictionaries may vary widely. Dictionaries often compromise with respect to the comprehensive inclusion of technical terms. The reason given for this is usually the fact that technical terms have a limited usage frequency. With regard to the microstructure, most comprehensive dictionaries differ with respect to the variety of information types and the relative exhaustiveness of their presentation. Consequently, in its policy statement the Bureau has kept in mind that the WAT can never be completely comprehensive in all respects.

Language usage can be insulting to such an extent that the social structure of the language users is seriously affected. Such language usage may consequently lead not only to an alienation from the products of the language, but also from the language itself.

At the international congress on the treatment of insulting and sensitive lexical items in the WAT (Stellenbosch, 8 - 10 Feb. 1994), Prof. Vernon February pointed to the essential characteristic of racist terms which distinguish them from other insulting terms, for example obscenities. A racist term refers almost exclusively to an attribute which can in no way be altered. It is used to indicate a certain physical characteristic or supposed trait of the person mentioned. Nobody can do away with his or her ethnic origins. If you mock or insult the ethnic origin of somebody, you attack something which he or she can do nothing about.

Although the degree of hurtfulness of insulting lexical items is determined by their meaning in the first place and by the social attitudes which lead to their use in the second place, those against whom racist terms are aimed experience such terms as extremely hurtful precisely because of the stated characteristic of unalterability.

This characteristic of unalterability often also plays a role in the other categories of insulting lexical items which are under discussion. Examples of these are inter alia sexist terms, lexical items which denote stigmatized physical or mental conditions and phenomena amongst people, and lexical items which are sensitive on religious grounds. Compare in this respect vrouelis (woman's guile), mannemoed (manly courage), oumansklier ("old man's gland", prostate gland), mongool (mongoloid), idioot (idiot), vertraag (retarded), psigopaat (psychopath), haaslip ("hare's lip", cleft palate), horrelvoet (club foot), boggel (hunchback), skeel (cross-eyed), moffie ("queer", homosexual), poefter ("queer", homosexual), trassie ("transvestite", hermaphrodite), Katools ("Catholic", foolish, 
lecherous woman), soos ' $n$ Katoliek bid (to pray like a Catholic, with eyes half open in order to peep), Mohammedaan (offensive term for an Islamic person). In these categories the characteristic of unalterability is not absolute. General exceptions as well as differences in degree occur between and within most of these categories. In cases where unalterability does play a role - as with racist terms - such injurious references are also experienced as particularly hurtful.

In contrast to this, most lexical items which are experienced as sensitive in a certain political or social structure refer to something which can be altered to a certain extent. Compare in this respect agtergeblewene ("person left behind", disadvantaged person), armlastige ("poor nuisance", indigent person), plakker. (squatter), bloubaadjie ("blue jacket", traffic policeman), hond ("dog", policeman), platpoot ("flat foot", policeman), terroris (terrorist), vryheidsvegter (freedom fighter), comrade. Such lexical items can also be used in an insulting, hurtful or alienating manner. In this case, however, greater differences in degree are noted in the way they are experienced.

The climate in South Africa is particularly sensitive to the use of racist lexical items. At the above mentioned international congress the belief was expressed that this climate was of a temporary nature. At that stage it was nevertheless felt - although not by all - that the inclusion of racist lexical items in the WAT would be undesirable during this period of reconciliation. Such a move would not only hinder reconciliation, but it would at the same time result in greater alienation.

In its aims at comprehensiveness, the Bureau of the WAT does not want to be instrumental in the establishment or perpetuation of racist lexical items by means of inclusion in the WAT. It does, however, have a responsibility to warn users of the racist nature of certain lexical items. This it can only do if it identifies these lexical items and brings them to the attention of the user in some way or another.

In the same way, the Bureau does not want to encourage the use of sexist lexical items or lexical items which refer to a person with stigmatized physical or mental conditions or phenomena in an insulting or insensitive manner. It does, however, also here have the duty to identify them and to warn the user against their hurtful nature.

A factor which complicates the inclusion policy of the lexicographer is the fact that there are - as pointed out before - differences in degree not only between categories of insulting or sensitive lexical items, but also within one and the same category. Not even all racist language is experienced equally negatively. A simplex such as kaffer is experienced as particularly racist, while a compound with a racist component is not necessarily experienced as very racist. A compound such as kafferbrak ("kaffer dog", mongrel dog) is completely racist, while a term such as kafferwaatlemoen ("kaffer watermelon", wild melon) is relatively less racist. An expression such as alle kaffers het swart velle ("all kaffirs have black skins", blacks are unreliable), where race differences are used to insult somebody, is experienced.as extremely racist. 
In the treatment of insulting and sensitive language, the above mentioned differences between racist terms, sexist language and language with which stigmatized physical or mental conditions and phenomena among people, or religious, political and social differences are indicated, should be taken into account. Distinctions must also be drawn between the different types within each of these categories.

It was against this background that the Bureau formulated a provisional policy for the treatment of insulting and sensitive lexical items in the WAT and sent it not only to all the participants in the above mentioned congress, but also to language users, language practitioners, linguists and other important international lexicographers and metalexicographers for their comments. In essence, the policy proceeded from the following argument:

Since the WAT can never be completely comprehensive in all respects, and since technical language, without indignation or serious contradiction, constitutes an exception to the aim of comprehensiveness, it can be argued that even more of an exception should be made regarding language which is considered extremely hurtful and, just as is the case with technical language (but indeed for other reasons), usually has a limited frequency of use. Consequently it was suggested that no racist lexical items be defined in the WAT and that, with a single exception, no racist compounds be included. Simplexes of this nature are included, but purely with a reference to the complete treatment in electronic form which is available on request. Details regarding both these simplexes as well as their compounds can then be found here.

The Bureau received diverging reactions to this policy. It ranged from approval to conditional approval to serious criticism.

The most important criticism was:

(a) The Bureau should not now withhold information or practise self-censorship while the country is moving away from a political system which was criticised for its restriction of information.

(b) The Bureau creates a false impression of reality in the printed form of the WAT and is guilty of the falsification of history particularly with regard to the treatment of racist terms.

(c) It is the duty of a comprehensive dictionary such as the WAT to include, explain and provide usage information on all lexical items.

(d) The buyer of a censored WAT will be permanently bound to a dictionary which contains incomplete information.

(e) The electronic version is not accessible enough and can not claim to have the same permanence as the book.

(f) The implementation of the policy reveals a conspicuous discrepancy in the way different kinds of lexical items are treated.

(g) The policy is an overreaction to a problem which occurs worldwide, but which has been politicized here and will consequently disappear to a large extent. 
(h) In a hundred years from now the policy of the WAT will appear to be just as ridiculous as Victorian prudery.

Upon reflection, it is the opinion of the Bureau that it probably was not a valid argument in its proposed policy that the incompleteness of dictionaries regarding technical language was a motivation for the exclusion of racist lexical items. In this regard there is a valid difference between the technical and racist nature of lexical items: Highly advanced technical language can not insult anybody, therefore nobody needs to be warned against its use. Racist terms are always hurtful, therefore dictionary users should indeed be warned against their use. Racist terms and other insulting and sensitive lexical items can therefore not be left out of a comprehensive dictionary such as the WAT as easily as highly advanced technical language. Consequently, macrostructural comprehensiveness with regard to offensive and sensitive lexical items is of the utmost importance. This ensures the possibility of labelling each such lemma properly.

The Bureau is, however, of the opinion that microstructural comprehensiveness with regard to racist terms and other insulting and sensitive lexical items need not be strictly maintained, as long as the explanation of meaning takes place and the user is warned against the hurtful nature of the items.

The Bureau proposed an alternative policy for the treatment of insulting and sensitive lexical items in the light of the latter opinion and of the criticisms received of the first version of its policy, and also as a result of the positive change in social relations in South Africa (as specified below). The policy states that all such lexical items be included, labelled and explained in the printed form of the WAT, but that no collocations and editorial usage examples be given with them. In the case of racist terms, but not with other kinds of insulting and sensitive lexical items, no hurtful synonyms, no semantic oppositions, references and citations or other usage examples will be included. This excluded information, with the exception of collocations and editorial usage examples, as well as all citations which reflect a negative attitude towards any population group, is included in an electronic version. It can be made available to users in this form.

Since the presentation of the above mentioned international congress, South Africa has already experienced a year of democracy and a process of reflection and political as well as social catharsis has started. Most of the people who were wronged by the abuses of the past have started to express their humiliation, pain, protest, rage and sorrow on a personal level or in public. Guilt and regret concerning the grief caused have similarly been expressed and demonstrated by the other side. Already there were also signs of this process at the above mentioned international congress at Stellenbosch. A welcome spirit of forgiveness and reconciliation has developed as a result of these changes in a democratic South Africa. This was especially stimulated by the spirit of liberation since the election of 27 April 1994 and by the widespread 
confidence in the transitional government of the country.

It is in this spirit of reconciliation that reactions to the draft version of the Policy for the treatment of insulting and sensitive lexical items in the Woordeboek van die Afrikaanse Taal (WAT) have also been forthcoming. The Bureau can not speak on behalf of others and especially not on behalf of those who suffered the most under the previous dispensation of discriminatory racial separation and humiliation. Yet is was found that the international congress itself, together with ensuing discussions and the general reconciliatory spirit, to a great extent created an occasion for defusion and reflection. This was apparent from the spirit of the congress itself, from discussions later on with academic, political and community leaders, as well as from comments received on the congress. It appears as if the intensity of the experience particularly of racist terms is decreasing and has now reached almost the same level of sensitivity as with languages which have not been affected, like Afrikaans, by political and social tension. All this has happened in the course of one year of a new government. It seems that this reconciliatory spirit is to a greater extent becoming established on all levels of society.

It should also be noted that the strong reactions to the WAT were evoked by the grossly racist terms and other insulting material found in older volumes. These reactions were already not as negative towards the treatment of insulting and sensitive material in the latest WAT volumes. It could consequently be expected that the proposed treatment of such items as set out below will elicit a less vehement reaction or even no reaction at all.

It is against this background and with the consideration of the comments received that the policy as set out below was formulated.

\section{A. Racist terms}

Examples: aia (black woman servant, maid), Asiaat (Asiatic), Boesman (Bushman, San), Hottentot (Hottentot, Khoikhoi), kaffer, Kleurling ("Coloured person"), korlie (coolie, Indian person), bitterbek ("bitter mouth", brown or black person), hotnot ("Hottentot", brown person), Kaaskop ("cheese head", Dutchman), Rooinek ("red neck", Englishman), witvel ("white skin", white), zool (black), hotnotsblymaak ("Hottentot's happiness", drizzle which falls with brief interruptions), Kafferafrikaans (faulty Afrikaans as used by some blacks), koeliegriep ("coolie influenza", Oriental influenza), meidewerk ("(black or brown) maid's work", inferior work), witmanstaal ("white man's language", European language), hotnotskooigoed ("Khoikhoi bedding", soft, grey, woolly herbaceous plant), kafferblom ("kaffer flower", poinsettia), kakiebos ("English soldier's bush", any of a range of weeds), boesmanrys ("Bushman's rice", termite larvae), hottentotsgot ("Hottentot's god", different kinds of carnivorous insects of the Mantidae family), kafferkraai ("kaffir crow", trumpeter hornbill), Boesmanland ("Bushman country", geographical name, which could be offensive in the metalanguage), 
Hotnotsbaai ("Hottentot's bay", geographical name, which could be offensive in the metalanguage), Kafferberg ("kaffir mountain", geographical name, which could be offensive in the metalanguage), Meidekop ("(black or brown) maid's hill", geographical name), Boere ("(white) farmers", Afrikaners; the police; prison warders), Franse siekte ("French illness", syphilis), lood ("Jew", miserly, avaricious person; shrewd businessman; usurer), Spanjools (derogatory term for Spaniard), ' $n$ Boesmantjie doodslaan ("to kill a little Bushman", to sleep badly; to enjoy a drink; to be restless, hurried), los hotnot ("loose Hottentot", somebody without work or other commitments, who is free to come and go as he or she pleases, a (grass) widow or (grass) widower), koelietaal vir iemand wees ("to be coolie language for someone", to be incomprehensible to somebody).

\section{Treatment in the WAT}

The concept "racist term" must be clearly defined in the User's Guide for each volume of the WAT. Racist lexical items will be considered for inclusion only if they conform to the general usage criterion of the Bureau.

A distinction is drawn between wholly racist lexical items and partially racist lexical items. Wholly racist lexical items are simplexes such as hotnot and kaffer and compounds such as hotnotstaal (the language of the "hotnot", a derogatory reference to Afrikaans), kafferbrak and uitkaffer ("kaffir out", to insult someone) of which all the distinctions are racist. Partially racist lexical items are polysemic terms such as boer (white Afrikaner person, farmer) and meidjie (young, black or brown maid, endearing term for a woman) of which there are neutral semantic distinctions. The term boer, for example, can in the first place also mean "someone who farms", while the term meidjie is used as a term of endearment for addressing female persons. This also applies to polysemic compounds of which the components themselves are not racist, but the whole is indeed so, for example gifasem ("poison breath", black person) and houtkop ("wooden head", black person).

(a) Wholly racist lexical items

All simplexes, compounds and expressions are included as lemmata and treated subject to the additional conditions below.

- Lemmata are labelled as follows: rassisties; die gebruik hiervan is uiters neerhalend en aanstootlik. This label is clearly explained in the User's Guide.

The metalanguage is as neutral and sensitive as possible.

Sensitivity should also be shown in the metalanguage to terms which are likely to become non-neutral for language users in future, for example 
inboorling (native). It would be better in such a case to use a term like outogtoon (autochton) or a description such as "indigenous inhabitant of ...".

- A racist lexical item is referred to the only or most commonly used synonym for the definition in the case where one or more neutral synonyms exist, regardless of the common usage of the racist lexical item referred. No racist synonyms are, however, given at neutral or racist lexical items.

- No semantic oppositions, such as antonyms, are given.

- No illustrative material, i.e. collocations, editorial usage examples or citations, are given. The Bureau does not want to provide any encoding information regarding racist lexical items in the printed WAT.

- Expressions containing these lexical items are included and explained, but no racist or neutral synonyms, antonyms or references to other lexical items in the WAT and no illustrative material are given with such expressions. The expression ' $n$ los hotnot will for example be included in the article of the lemma los and the expression koelietaal vir iemand wees will be included in the article of the lemma koelietaal, but will be treated in the restricted manner referred to.

The same manner of treatment applies to racist expressions under a neutral lemma, i.e. expressions of which none of the components are racist, but the whole is in fact so (e.g. kort voor die stroois omgedraai hê, "tumed back just before reaching the hut", to be of mixed blood).

- For a complete treatment of the lemma concerned - including expressions containing the lemma - or of a racist expression under a neutral lemma, the user is referred in the User's Guide to the electronic manuscript of the Bureau, which is available in electronic form on request. The following formulation may be used for this purpose: "Raadpleeg die Buro se elektroniese manuskrip vir 'n volledige bewerking van hierdie leksikale item." At the racist lemma or expression, the user is referred to the User's Guide.

\section{(b) Partially racist lexical items}

All simplexes, compounds and expressions are included as lemmata and treated subject to the additional conditions below.

Neutral semantic distinctions are treated in full.

Racist semantic distinctions and expressions are labelled rassisties; die gebruik hiervan is uiters neerhalend en aanstootlik (racist; the usage is extremely derogative and offensive), and are further treated exactly as wholly racist lexical items under (a) above.

The Bureau of the WAT reserves the right to review the policy regarding the treatment of racist terms after deliberation and as the climate concerning the experience of racist terms changes. If the experience of sensitive language 
should become less traumatic in the course of time, it would perhaps become possible to examine racist terms in a more clinical manner. Especially compounds which have term status, such as kafferwaatlemoen ("kaffir water-melon", wild melon), hottentotsgot, boesmanrys and meidebossie ("(black or brown) maid's bush", a medicinal plant used by Shangaan women for barrenness) and which are not experienced to be as racist as simplexes and expressions, could for example at a later stage be reconsidered for a more complete treatment regarding the provision of synonyms, antonyms, references and usage examples in the form of citations.

\section{Treatment in the electronic manuscript}

- All racist lexical items which have been included in the printed version of the WAT in a scaled-down form are treated more comprehensively in the electronic version and are stored in electronic form for availability. This is done subject to the additional conditions below.

- The labelling of these lexical items takes place in a careful and sensitive manner. Allowances are made to indicate differences in the degree of racism attached to the lexical item or semantic distinction (cf. meidebossie, meid ("(black or brown) maid") and soos 'n meid lag ("to laugh like a (black or brown) maid")). The labels used to indicate such differences in degree are explained in the User's Guide.

- The metalanguage is as neutral and sensitive as possible, and lexical items which are not likely to have a neutral value for language users in the future, for example inboorling, are avoided in the metalanguage.

- References to or the noting of synonyms or semantic oppositions are given with neutral as well as non-neutral lexical items.

- Collocations and editorial usage examples are not included.

- Usage examples in the form of citations are given, but are chosen carefully. No citations are included in which racist terms are used to express a negative attitude towards any population group. An utterance such as 'n Mens kan nie 'n kaffer met die bouwerk vertrou nie (You can not trust a black person with the building process) is not acceptable as illustrative material. Furthermore, no citations are included in which the phenomenon, the practice or the consequences of racism are approved of.

- The contents of the electronic manuscript will be available on request and in terms of the prevailing policy of the Bureau.

- Articles of racist lexical items in both the printed WAT as well as the electronic manuscript are checked for correctness and sensitive treatment by advisors to the Bureau. 


\section{B. Sexist terms and sensitive lexical items which indicate stigmatized sexual phenomena, practices and preferences among people}

Examples: vrouelis (woman's guile), verwyf ("effeminate"), ouvroustories (old wives' tales), oujongnooi ("old young girl", spinster), swakker vat (weaker sex), mannemoed (manly courage), oumansklier ("old man's gland", prostate gland), oujongkêrel ("old young boy", bachelor), gigolo (man maintained by a woman), hoer (whore), snol (tart, harlot), agtermekaarkêrel ("behind one another chap", a pun on the neutral sense "fine chap", male homosexual), haas ("queer"), kween ("infertile cow", slut, childless or infertile woman), manvrou ("butch" woman), moffie ("queer"), poefter ("queer"), sodomieter (sodomiter), trassie ("transvestite", hermaphrodite).

This category is considered rather broadly, since not all sensitive lexical items contained in it are considered hurtful towards a certain sex or offend the sexuality of somebody.

The Bureau does not intend to perpetuate or entrench any sexually discriminating hierarchy, but aims instead to play a role in the equalization of the sexes. It also aims to be neutral towards different sexual phenomena, orientations, practices and preferences. In the light of this, the following treatment policy is followed:

Sexist lexical items will only be considered for inclusion if they meet the general usage criterion of the Bureau.

All sexist lexical items which meet this condition, are included and treated in full, with due observance of the additional conditions below.

- Sensitivity is practised in the metalanguage regarding terms which are experienced as sexist, or are likely to be experienced as such in the future.

- Common or neutral pronouns and other references are used in the metalanguage. A repetition of he/she or him/her is generally experienced as disturbing by the reader. Therefore the following formulations are recommended: "Iem. wat ..." ("Someone who ..."), "Persoon wat ..." ("Person who ..."), "T.o.v. volwassenes" ("Regarding adults" instead of "Regarding a man or woman"), "T.o.v. kinders" ("Regarding children" instead of "Regarding boys or girls"), or "T.o.v. mense" ("Regarding people"), etc.

- Sexually offensive lemmata are clearly labelled as seksisties and the label is explained in the User's Guide to each volume of the WAT.

Where possible and regardless of the conventionality of the non-neutral lexical item, the definition is given at the most commonly used neutral synonym. A descriptive definition would thus be given at vrygesel (bachelor), while oujongkêrel would be referred to vrygesel. Similarly, a descriptive definition would be given at homoseksueel (homosexual), while moffie would be defined as manlike homoseksueel (male homosexual), which contains an indirect reference to a synonym. 
- Reference from the hurtful to the neutral synonym, and vice versa, takes place completely. Oujongkêrel will thus be referred to vrygesel, and vice versa. All sexually offensive synonyms at a neutral lemma are labelled clearly as sexist at the relevant lemma. Antonyms and other references are also given.

- Collocations and editorial usage examples are not included.

- Usage examples of use in the form of citations are given, but carefully chosen. No citations are included in which a sexist term is used to express a negative attitude towards a particular sex. An utterance such as Geen man sal na ' $n$ tipiese oujongnooi kyk nie (No man would look at a typical spinster) is not acceptable. Neither are citations included in which the phenomenon, practice or consequences of sexism are approved of. In the choice of illustrative material a balance between citations referring to male role players and citations in which female role players feature, is aimed at. These conditions also apply to citations in articles of neutral lemmata.

- Expressions containing a sexist lexical item, for example soos ' $n$ viswyf skel (to rave like a fish vending hag, fishwife), are included and treated in the normal manner, except that here too no collocations or editorial usage examples are given.

- In order to ensure that no discrimination through omission takes place against any sex or against any sexual preference, for example by ignoring certain lexical items on sexist grounds or because offence will be taken by other groups, all forms of literature will be excerpted on an even more representative manner for such material. In this way the Bureau hopes to present a correct and balanced picture of such material.

Articles of lexical items in this category are checked for correctness and sensitive treatment by advisors to the Bureau.

\section{Sensitive lexical items which indicate stigmatized physical or mental conditions and phenomena among people}

Examples: gebreklik (decrepit), gestrem (retarded), tartie (derived from "retarded"), kinderverlamming (infantile paralysis), haaslip ("hare's lip", cleft palate), boggel (hunchback), horrelvoet (club foot), skeel (cross-eyed), blind (blind), doof (deaf), doofstom (deaf and dumb), hardhorend (hard of hearing), swaksiende ("weak-sighted", with impaired vision), stokblind ("as blind as a stick", totally blind), stokdoof ("as deaf as a stick", totally deaf), doof soos ' $n$ kwartel ("as deaf as a quail", totally deaf), kruppel (crippled), lam (lame), melaats (leperous), mongool (mongoloid), idioot (idiot), eenvoudig van gees (simpleminded), geestelik versteurd (mentally deranged), sielsiek ("soul-sick", mentally deranged), vertraag (retarded), mal (mad), kranksinnig (insane), psigopaat (psychopath), waterhoof ("water head", hydrocephalus). 
Although the characteristic of unalterability applies to most of the sensitive lexical items in this category, they are not experienced as hurtful as racist terms because they are used to a lesser extent to deliberately insult those involved. Reference plays a larger role here than typification and insult. With this distinction in mind, the following methods of treatment are followed:

- Sensitive lexical items in this category will only be considered for inclusion if they meet the general usage criterion of the Bureau.

All lexical items which meet this condition are included and treated in full with due observance of the additional conditions set out below.

Full treatment includes the indication of synonyms, antonyms and other references. Reference from the hurtful to the neutral synonym and vice versa thus occurs. Each hurtful synonym under a neutral lemma is labelled accordingly at the relevant lemma.

Sensitive lexical items are used with great circumspection in the metalanguage.

Non-neutral lexical items are labelled. These labels are clearly explained in the User's Guide of each volume of the WAT.

Where possible and regardless of the conventionality of the non-neutral lexical item, the definition is given at the neutral synonym most used. Haaslip will for example be referred to gesplete lip and mongolisme to Downsindroom. If no neutral synonym exists, the non-neutral lexical item is treated in full.

In the case of sensitive lexical items such as haaslip, horrelvoet, doof and blind, there are differences in the degree of sensitivity attached to the lexical items. Somebody who is really blind, will experience the designation blind as reasonably neutral. Someone whose eyesight has been affected to a lesser degree, will experience blind not only as a misnomer, but also as injurious. The same applies to doof $x$ hardhorend. The possibility of including a semantic distinction which distorts the facts must be guarded against. A label at the lemma blind will indicate that it is sometimes experienced as injurious by those called such.

Differences in degree occur not only between semantic distinctions within the same article (for example blind), but also between different lexical items. Therefore haaslip should have a more markedly censuring label than for example horrelvoet. Haaslip is particularly injurious because a human characteristic is related to that of an animal. The same applies to lexical items where use is made of intensification. Thus stokblind is more injurious than blind and so doof soos ' $n$ kwartel is more injurious than doof. In the latter case there is even increased injuriousness: not only does intensification through comparison take place, but the comparison is moreover with an animal characteristic. All these differences play a role in the distinction of degrees by means of labels. Collocations and editorial usage examples are not included. 
- Usage examples in the form of citations are given, but are carefully chosen. No citations are included in which a hurtful designation of this kind is used to express a negative attitude towards persons who show stigmatized physical or mental conditions or phenomena. An utterance such as Weens hulle onselfstandigheid is die blindes ' $n$ las op die samelewing (Due to their dependence, the blind are a burden to society) is not quotable. Neither are citations included in which discrimination in this sphere is regarded with approval.

- Expressions in which lexical items occur which point to stigmatized physical or mental conditions and phenomena among people are given strongly condemnatory labels. The relevant expressions (cf. blind soos ' $n$ mol ("as blind as a mole", very blind) and melaats wees ("to be leperous", to be avoided) are treated in full.

Articles of lexical items in this category are checked for correctness and sensitive treatment by advisors to the Bureau.

\section{Sensitive lexical items within a social, political and religious structure}

Examples: armlastige ("poor nuisance", pauper), agtergeblewene ("person left behind", disadvantaged person, social drop-out), minderbevoorregte (less privileged), onderontwikkelde (underdeveloped), plakker (squatter), lokasie ("location", ghetto), bloubaadjie ("blue jacket", traffic policeman), hond ("dog", policeman), platpote ("flat foot", policeman), kapitalis (capitalist), kommunis (communist), civics, comrade, demand, toi-toi (dance of rallying demonstrators), regime, struggle, terroris (terrorist), vryheidsvegter (freedom fighter), Dopper ("villager", derived from Dutch "dorper"; member of the Reformed Church of South Africa), Gatjieponner ("wearer of the anal coat", derived from "gatjapon", tailcoat; member of the Dutch Reformed Church of South Africa), heppiekleppie ("happy clappy", member of a church where hands are clapped), Katools ("Catholic", foolish, lecherous woman), soos ' $n$ Katoliek bid (to pray like a Catholic, with eyes half open in order to peep), dogterkerk ("daughter church", church denomination lesser than another), sektekerk (sectarian church), Gam (Ham, Biblical figure; brown or black person), Mohammedaan (offensive term for an Islamic person), Moslem (instead of Moesliem, Muslim), Slams (offensive term for Islamic), soos in 'n Jodekerk wees ("to be as in a Jewish synagogue", noisy).

All lexical items in this category, including those which denote something which is alterable, could be used or experienced as insulting, hurtful or alienating. Compare in this regard agtergeblewene, armlastige, plakker, regime, platpote, terroris. The degree of humiliation is not the same with each lexical item and is also not always predictable. The policy for the treatment of such lexical items follows below:

Sensitive lexical items in this category will only be considered for inclusion if they meet the general usage criterion of the Bureau. 
All lexical items which meet this condition are included and treated in full with due consideration to the additional conditions set out below.

Treatment in full includes the indication of synonyms, antonyms and other references. References from the hurtful to the neutral synonym, and vice versa, for example, are given in full. Each hurtful synonym under a neutral lemma is labelled appropriately at the relevant lemma.

- These lexical items are as far as possible not used in the metalanguage. Furthermore, lexical items which currently do not, or may in all likelihood in the future not have a neutral value for language users, must at all costs be avoided in the metalanguage.

- Appropriate labels indicate the sensitive nature of dissimilar cases, for example regime, platpoot and bloubaadjie (neerhalend, "derogatory") versus struggle, demand and comrade (in bepaalde politieke kringe as distansiërend ervaar). These labels are explained in the User's Guide of each volume of the WAT.

Collocations and editorial usage examples are not included.

Usage examples in the form of citations are given but carefully chosen. No citations are used in which social or political groups, religions or religious bodies are offended. An utterance like Die plakkers het vanweë ontoereikende behuising baie koud gekry toe die Kaapse winter toegeslaan het (Due to the inadequate housing, the squatters were very cold when the Cape winter set in) is acceptable, while Die plakkers leef soos diere in krotte (The squatters live like animals in hovels) is not. Furthermore, no citations are included in which the abuses of a certain social or political structure are approved of.

- In order not to discriminate in particular against different political and religious groups through omission, for instance by ignoring their linguistic expressions on the ground of ideological or theological apathy or because certain lexical items could offend other groups, all kinds of literature will be excerpted in an even more representative manner also for such material. In this way the Bureau hopes to give a correct and balanced image of such material. This applies particularly to words such as comrade, toi-toi, struggle and vryheidsvegter.

Articles of lexical items in this category are checked by the Bureau's external advisors for correctness and sensitive treatment. For this purpose articles of sensitive lexical items in the field of politics and religion are submitted to knowledgeable and recognised representatives of political groups and religious bodies.

\section{E. Obscene and vulgar lexical items, abusive language and swear-words}

Examples: bedonderd ("to be with, like thunder", hard-headed, difficult, angry), fok (fuck; also as swear-word), fokken (fucking), kakpraat (talk crap), opdonder 
("thunder up", beat up), opneuk ("fuck up", beat up), opmoer ("mother up", beat up), naai ("sew", fuck), pis (piss), skyt (shit), stront (shit; also as abusive language and swear-word), esel (mule; as abusive language), hond (dog; as abusive language), vark (pig; as abusive language), moerskont ("mother cunt"), verdomp (damn), vuilgoed (rubbish, as abusive language), allemagtig (Almighty; as swearword), bliksem ("lightning"; as swear-word), hel (hell; as swear-word), Here (God; as swear-word).

All the lexical items in this category can offend or can be used to insult and injure or can be experienced as such. The degree of hurtfulness is not the same with each lexical item and also not always predictable. Obscene and vulgar language is not for example regarded in every company or social atmosphere as being in equally bad taste. In the case of abusive language and swear-words, it is the social attitude of the user which is of primary importance. However, the meaning and connotation is also significant here. People are for example usually more offended if in abusive language they are compared to a pig rather than to an ass or a buffalo. In swear-words where the Deity is mentioned by name, the religious attitude and affiliation of the hearer is in turn of great importance to the experience thereof. Furthermore, the characteristic of alterability plays an important role in the hearer's experience of abusive language and swear-words. The following treatment policy is therefore followed by the Bureau:

- Sensitive lexical items in this category will only be considered for inclusion if they meet the general usage criterion of the Bureau.

All lexical items which meet this condition, are included and treated in full with due consideration to the further conditions set out below.

Treatment in full includes the indication of synonyms, antonyms and other references. Reference from the hurtful to the neutral synonym, and vice versa, thus occurs. Each hurtful synonym under a neutral lemma is labelled appropriately at the relevant lemma.

- Sensitive lexical items are labelled. These labels are clearly explained in the User's Guide of each volume of the WAT.

Where possible and regardless of the conventionality of the non-neutral lexical item, the definition is given at the neutral synonym most used. Thus pis (in its different parts of speech functions) will for instance be referred to urine and urineer. If no neutral synonym exists, the non-neutral lexical item is treated in full.

These lexical items are, as far as possible, not used in the metalanguage, except in their neutral values, as with esel, hond, vark, vuilgoed, bliksem, hel, Here.

Collocations and editorial usage examples are not included.

Usage examples in the form of citations are given, but are carefully chosen. No citations are used in which religious, social or political groups may be offended. This also applies to citations in articles of neutral lemmas. 
Articles of such lexical items which apply to religions with which the editors are not fully familiar, are checked by recognised advisors from these religious bodies as regards correctness and sensitive treatment.

\section{Concluding remarks}

It has already been pointed out that a dictionary can never be completely comprehensive in its inclusion of lexical items and also that although the reasons for this may differ, the results are the same, viz. incompleteness. Thus complete comprehensiveness can never be expected of a dictionary. The demand can however be made to a scientifically compiled comprehensive explanatory dictionary such as the WAT that contemporary language usage be included and interpreted (decoded) in a representative manner. This also applies to the inclusion of racist terms and other sensitive lexical items.

Such representativeness makes a comprehensive explanatory dictionary a mirtor of its time. A dictionary of this kind may never distort the linguistic and social reality by for example selective inclusion and false representations. The WAT should not and will not fail in its duty to be a true mirror of its time, but it also does not want to contribute to the disruption of the social structure by an insensitive treatment of racist and sexist terms in particular.

Although a comprehensive explanatory dictionary aids the language user in actively using language, i.e. to encode concepts, the Bureau feels that it is not its task to bring such injurious lexical items to the attention of the dictionary user for this encoding purpose. On the contrary, it feels that it is its duty rather to inform the user of the hurtfulness thereof and to further decode these items purely in a sensitive manner. The Bureau thus aims to play a socially standardizing role rather than a socially disruptive role. This is done to promote the communicative use of Afrikaans by all its speakers and thereby to improve human relations in this country.

Also the mere inclusion of insulting and sensitive lexical items during a period of socio-political transition, as is currently the case in South Africa, may be experienced as hurtful. The Bureau thus needs to maintain a fine balance between its mirroring and its standardizing functions. With respect to racist terms, this can best be done by presenting only the most necessary information for adequate decoding and labelling in the printed form of the WAT, but to treat these items comprehensively in electronic form. In both cases this material is constantly handled with caution. The electronic manuscript will then be made available to bona fide users of the WAT on request and in accordance with the Bureau's prevailing policy. Thanks to modern computer technology and electronic means of communication this way of handling the electronic manuscript can already be put into practice by the Bureau.

It is in this way that the Bureau plans to compile an archival computer database of racist language. Thereby it first of all aims to perform its duty as 
an accurate mirror of its time without contributing to the disruption of the social structure by an insensitive treatment of such lexical items. Secondly, it seeks to avoid becoming guilty of the falsification of history.

To summarize, the Bureau's standpoint underlying its policy can be stated as follows:

- The Bureau is constantly aiming at comprehensiveness in the recording of Afrikaans lexicon.

- The Bureau is constantly aiming to make the macrostructure as well as the microstructure of the WAT as comprehensive or rather as representative as possible.

The comprehensiveness of the microstructure does not have to be reflected exclusively by the printed version of the WAT. The electronic medium can consequently be employed to supplement the printed WAT in the field of sensitive lexical items in order to present a representative picture of Afrikaans.

The Bureau believes that with this policy for the treatment of insulting and sensitive lexical items in the WAT it shows not only an understanding of a problem which caused great pain, indignation and interpersonal alienation in South Africa, but that it is also doing something to help rectify the problem without becoming disloyal to its assignment and typological nature. 